\title{
BLOK BAHAN PASANGAN DINDING (BBPD) DARI BAHAN BEKAS BONGKARAN BANGUNAN DENGAN PEREKAT LATEKS
}

\author{
I Nyoman Arya Thanaya ${ }^{1}$, I Nyoman Karnata Mataram², I Wayan Edi Arta Rimbawa ${ }^{3}$ \\ ${ }^{1}$ Program Studi Teknik Sipil, Universitas Udayana, Denpasar, Indonesia \\ ${ }^{2}$ Program Studi Teknik Sipil, Universitas Udayana, Denpasar, Indonesia \\ ${ }^{3}$ Program Studi Teknik Sipil, Universitas Udayana, Denpasar, Indonesia \\ e-mail: aryathanaya@unud.ac.id
}

\begin{abstract}
Abstrak
Diperlukan upaya untuk memanfaatkan bekas bongkaran bangunan untuk blok bahan pasangan dinding (BBPD) dan penggunaan lateks sebagai pengganti semen. Tujuan penelitian ini adalah untuk untuk menganalisis karakteristik BBPD. Agregat dari bekas bongkaran bangunan dan beton bekas dipecahkan secara manual, kemudian diayak dan diproporsikan dengan cara coba-coba untuk mendapat bentuk sampel yang stabil dan kompak. Kadar lateks dan tingkat pemadatan divariasi. Material dicampur rata dan dipadatkan, kemudian di oven pada suhu $40^{\circ} \mathrm{C}$ selama $\pm 6 \times 24$ jam sampai berat konstan. Dibuat juga sampel yang di kondisikan pada suhu ruang dan dites pada umur yang bervariasi. Didapatkan kadar residu lateks minimun yang diperlukan adalah 5,56\% dari berat total agregat. Kuat tekan BBPD dapat mencapai 34,95 $\mathrm{kg} / \mathrm{cm}^{2}$.
\end{abstract}

Kata kunci: bahan dinding, agregat bekas, lateks, kuat tekan

\begin{abstract}
It is needed to utilize construction demolition waste (CDW) as wall block masonry (WBM) and latex as substitute of cement. The research objective was to analyze analyze the properties of WBM. The CDW and waste concrete were manually crushed, then sieved and proportioned by trial to obtain a stable and compact sample shape. Variation of latex content and compaction level were carried out. The materials were evenly mixed and compacted then cured in oven at $40^{\circ} \mathrm{C}$ for $\pm 6 \times 24$ hours until achieve constant weight. Samples were also made and cured at room temperature and tested at various ages. It was obtained that the minimum latex content required was $5.56 \%$ of the total weight of aggregates. The compressive strength of the WBM can achieve $34.95 \mathrm{~kg} / \mathrm{cm}^{2}$.
\end{abstract}

Keywords : masonry block, waste aggregate, latex, compressive strength

\section{PENDAHULUAN}

Ketersediaan agregat alam semakin terbatas. Untuk itu perlu dilakukan penggunaan agregat bekas, diantaranya dari bongkaran bangunan dan bngkaran beton. Pada kondisi tertentu bisa tersedia banyak bongkara bangunan, diantaranya akibat bencana alam seperti gempa, banjir dan setelah terjadi kerusuhan.
Sejauh ini bongkaran bangunan banyak dipakai bahan urugan. Perlu diteliti pemakaiannya untuk bahan bangunan. antara lain digunakan sebagai bahan blok pasangan dinding (BBPD).

Sebagai bahan perekat BBPD umumnya digunakan semen, yang ketersediaanya di daerah tertentu (pedalaman) bisa terbatas karena keterbatasan sarana transportasi. Sebagai

*Corresponding author.

Received 31 Mei 2020; Accepted 30 Agustus 2020; Available online 15 Oktober 2020 (C) 2020 JST. All Rights Reserved 
alternatif penggnati semen dapat digunakan lateks. Indosesia memiliki iklim dan areal yang luas dimana budidaya pohon karet yang menghasilkan lateks dapat dikembangkan. Menurut Industri Karet (2008) karet alam merupakan polimer yang terdiri dari 5000an unit isoprene yaitu rantai polimer (C5H8)m, dimana " $m$ " merupakan koefisien polimerisasi.

Untuk memperoleh lateks perlu dilakukan penyadapan getah pohon karet dari pohon yang berumur 5-6 tahun, sudah memiliki lilitan batang yang cukup untuk proses penyadapan. Penyadapan lateks dilakukan pagi hari dimana getah karet memiliki tekanan turgor yang tinggi. Lateks memiliki partikel dengan daya lengket sehingga dapat digunakan sebagai perekat. Daya rekat partikel karet kurang baik sehingga dan cocok untuk merekatkan bahan-bahan ringan. Lateks dengan rantai molekul yang lebih pendek, memiliki daya rekat yang lebih baik (Alfa \& Syamsu, 2004).

Lateks berupa cairan berwarna putih sampai kekuning-kuningan dan banyak digunakan sebagai bahan baku pembuatan lem dan barang dengan bahan dasar karet (Nurhayati, 2008). Kandungan lateks segar terdiri dari $25-40 \%$ karet dan $60-75 \%$ material bukan karet. Bahan bukan karet ini terdiri dari air, protein, karbohidrat dan lipida (Wahyudi, 2008).

Hasil penelitian (Thanaya, 2010) menyatakan bahwa BBPD yang terbuat dari berbagai agregat bekas dengan perekat aspal memiliki sifat-sifat teknis yang memuaskan. Hal ini juga dilakukan oleh (Arissa, 2016) dan (Yudistira, 2017) dengan hasil yang cukup baik yaitu memiliki kuat tekan lebih besar dari minimal $25 \mathrm{~kg} / \mathrm{cm}^{2}$ (DSN, 1989). Selain itu perekat dapat juga menggunakan lemak minyak jelantah (Rambu, 2011). Dalam penelitian ini akan dikarakteriasi BBPD dengan menggunakan perekat lateks sebagai alternatif bahan alami yang berkelanjutan (sutainable) dan tersedia secara alamiah di Indonesia.

\section{METODE \\ Bahan dan Alat}

Bahan yang digunakan BBPD dalam penelitian ini adalah agregat bekas dari bongkaran beton, bongkaran tembok bata merah, bongkaran tembok batako, dan filler (material lolos $0,075 \mathrm{~mm}$ ) berupa material kombinasi bahan bekas dengan tambahan abu sekam dan perekat lateks. Penelitian dilakukan di Laboratorium Bahan Jurusan Teknik Sipil Fakultas Teknik Universitas Udayana, Bukit Jimbaran, Badung. Alat-alat yang digunakan antara lain, timbangan, satu set saringan, mesin pengguncang saringan, cetakan benda uji, alat penumbuk manual berupa alat tumbuk Marshall, dongkrak ejektor sampel, dan oven.

\section{Metode Penyiapan Agregat dan Proporsi Agregat}

Bongkaran banguan dipecahkan secara manual dan diayak dan dipilah. Agregat kasar (19-4,75 mm) diperoleh dari pemecahan beton, agregat halus (4,75 $0,075 \mathrm{~mm}$ ) dari serpihan sisa hasil pemecahan beton untuk agregat kasar, dan dari bongkaran tembok bata, dan batako. Material diproporsikan sesuai dengan gradasi yang sudah di tentukan berdasarkan hasil percobaan sebelumnya (Yudistira, 2017) dapat dilihat pada Tabel 1 dan 2. Dimana komponen filler (material lolos ayakan $0,075 \mathrm{~mm}$ ) terdiri $5 \%$, termasuk 2 persen abu sekam tambahan. Kebutuhan Lateks disajikan pada Tabel 3.

Tabel 1. Proporsi agregat

\begin{tabular}{|c|c|c|c|c|}
\hline $\begin{array}{c}\text { Jenis } \\
\text { Agregat }\end{array}$ & $\begin{array}{l}\text { Diameter } \\
(\mathrm{mm})\end{array}$ & Material & $\begin{array}{c}\text { Proporsi } \\
(\%)\end{array}$ & $\begin{array}{c}\text { Per } 3000 \text { gram } \\
\text { Agregat }\end{array}$ \\
\hline Agregat & $19-9,5$ & Bongkaran beton & 20 & 600 \\
\hline Kasar & $9,5-4,75$ & $\begin{array}{l}\text { Bongkaran beton } \\
\text { Bongkaran beton bata merah dan }\end{array}$ & 30 & 900 \\
\hline $\begin{array}{l}\text { Agregat } \\
\text { Halus }\end{array}$ & $4,75-0,075$ & batako yang divariasi & 45 & 1350 \\
\hline
\end{tabular}




\begin{tabular}{ccccc}
\hline $\begin{array}{c}\text { Jenis } \\
\text { Agregat }\end{array}$ & $\begin{array}{c}\text { Diameter } \\
(\mathbf{m m})\end{array}$ & Material & $\begin{array}{c}\text { Proporsi } \\
(\%)\end{array}$ & $\begin{array}{c}\text { Per } \mathbf{3 0 0 0} \text { gram } \\
\text { Agregat }\end{array}$ \\
\hline & & & & \\
Filler & Lolos 0,075 & Filler & 5 & 150 \\
\hline & & & $100 \%$ & 3000 \\
\hline
\end{tabular}

Tabel 2. Proporsi komponen filler

\begin{tabular}{ccccc}
\hline $\begin{array}{c}\text { Ag. kasar } \mathbf{5 0} \% \\
(\mathbf{1 9}-\mathbf{4 , 7 5} \mathbf{~ m m})\end{array}$ & \multicolumn{2}{c}{ Agr.Halus 45\% $(\mathbf{\leq 4 , 7 5}-\mathbf{0 , 0 7 5 m m )}$} & $\begin{array}{c}\text { Filler } \mathbf{5 \%} \\
\text { (lolos } \mathbf{0 , 0 7 5} \mathbf{~ m m})\end{array}$ \\
\hline $\begin{array}{c}\text { Bongkaran } \\
\text { beton }\end{array}$ & $\begin{array}{c}\text { Bongkaran } \\
\text { beton }\end{array}$ & $\begin{array}{c}\text { Bongkaran } \\
\text { tembok } \\
\text { batako }\end{array}$ & $\begin{array}{c}\text { Bongkaran } \\
\text { tembok bata }\end{array}$ & $\begin{array}{c}\text { Abu sekam dan } \\
\text { komponen filler } \\
\text { agregat bekas }\end{array}$ \\
$50 \%$ & $5 \%$ & $20 \%$ & $20 \%$ & $5 \%$ \\
\hline
\end{tabular}

Tabel 3. Kabutuhan lateks (kadar residu lateks 67,2\%)

\begin{tabular}{cccc}
\hline $\begin{array}{c}\text { Target Kadar } \\
\text { Lateks Resedu } \\
\text { (thd total berat camp) }\end{array}$ & Berat Lateks Resedu & $\begin{array}{c}\text { Kebutuhan } \\
\text { Lateks Cair }\end{array}$ \\
\hline $\mathrm{a}$ & $\mathrm{b}$ & & $\mathrm{C}=\mathrm{b} / 0,672$ \\
$(\%)$ & $(\mathrm{gr})$ & & $(\mathrm{gr})$ \\
5,05 & $=5,05 /(100-5,05) \times 3000$ & $=159,56$ & 237,44 \\
5,65 & $=5,65 /(100-5,65) \times 3000$ & $=179,65$ & 267,33 \\
6,65 & $=6,65 /(100-6,65) \times 3000$ & $=213,72$ & 318,02 \\
7,65 & $=7,65 /(100-7,65) \times 3000$ & $=248,51$ & 369,81 \\
\hline
\end{tabular}

\section{Pencampuran dan Pemadatan Sampel}

Material yang sudah diproporsikan sejumlah 3000 gram untuk satu sampel sesuai Tabel 1 dan Tabel 2, dilembabkan air secukupnya secara merata untuk memudahkan pengadukan, dan kemudian ditambahkan lateks cair sesuai kebutuhan (Tabel 3) dan diaduk rata. Pemadatan sampel dilakukan dengan menggunakan alat dan proses sesuai Gambar 1.

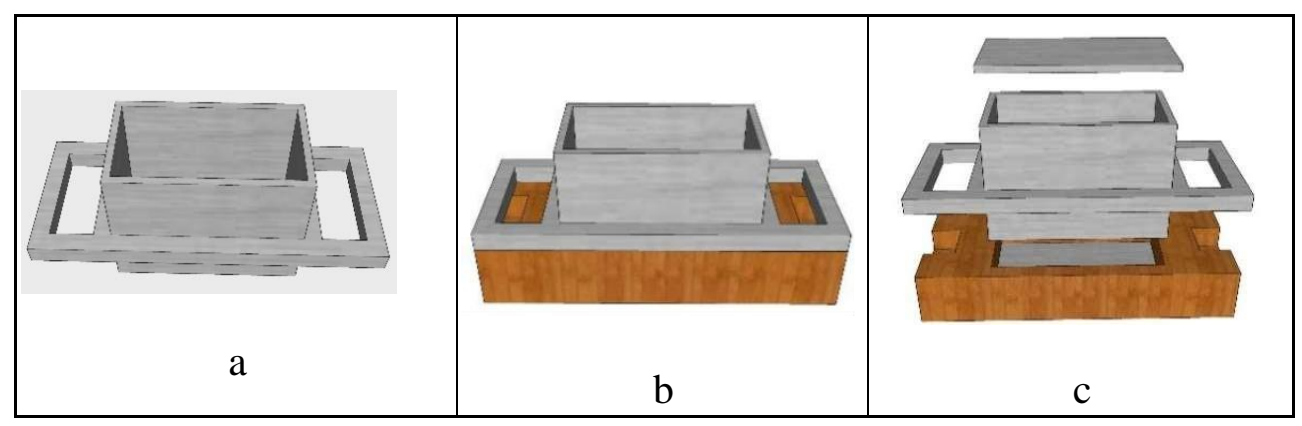




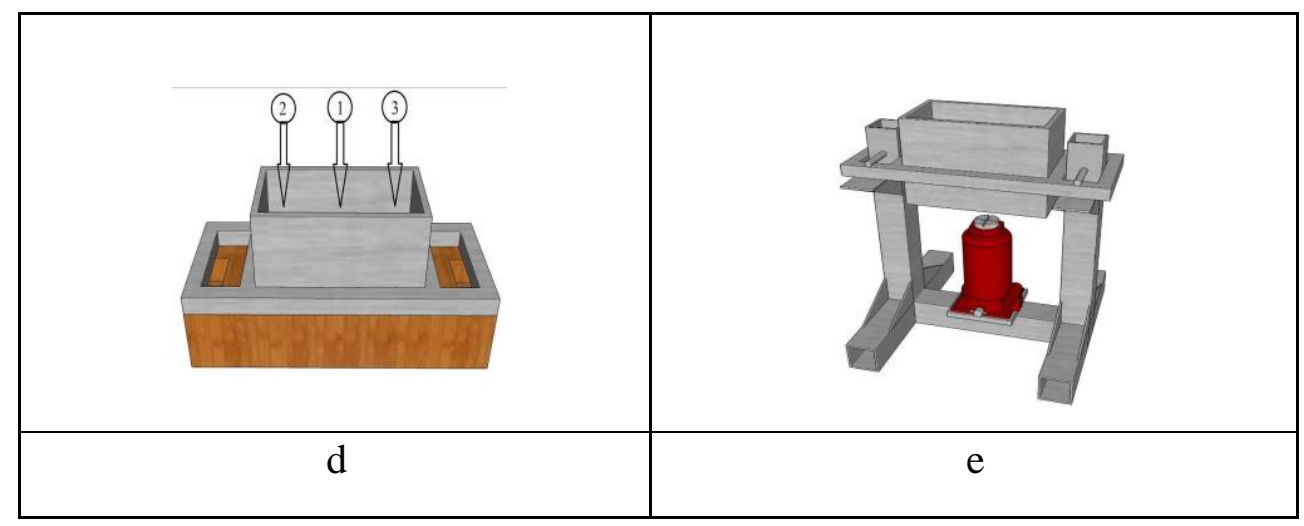

Gambar 1. Cetakan dan teknik pemadatan sampel

Cetakan sampel (Gambar $1 \mathrm{a}, \mathrm{b}, \mathrm{c}$ ) dibuat dari plat baja diberi alas plat baja $4 \mathrm{~mm}$ pada bagian bawah. Campuran yang sudah diaduk rata dimasukkan kedalam cetakan, diberi rojokan merata memakai batang besi diameter $10 \mathrm{~mm}$, kemudian dibagian atas diberi plat baja tebal $4 \mathrm{~mm}$ (Gambar 1c). Sampel kemudian dipadatkan memakai alat tumbuk Marshall. Untuk satu siklus pemadatan terdiri dari tiga tumbukan merata mulai dibagian tengah, kemudian dibagian sisi-sisi seperti diperlihatkan pada Gambarm 1d. Sampel yang sudah dipadatkan kemudian dikeluarkan dengan ejektor (Gambar 1e).

\section{Pengkondisian (curing) Sampel}

Sampel di kondisikan (curing) dalam oven pada suhu $40^{\circ} \mathrm{C}$ sampai semua kadar air menguap (berat konstan), dan di simpan pada suhu ruang $29-30^{\circ} \mathrm{C}$ dan diuji kuat tekan pada secara berkala untuk mengetahui peningkatan kekuatan sampai mencapai kekuatan relatif konstan.

\section{HASIL DAN PEMBAHASAN \\ Berat jenis material}

Berat jenis material disajikan pada Tabel 4. Dibandingkan dengan agregat alam yang berat jenisnya berkisar antara 2,30-2,50, agregat bekas bongkaran bangunan memiliki berat jenis relatif lebih kecil dan merupakan material yang tidak homogen kualitasnya, dimana bongkaran bangunan berasal dari beragam jenis bangunan yang kualitasnya memang kurang homogen. Sedangkan penyerapan materia disajikan pada Tabel 5 . Penyerapan agregat bekas lebih tinggi dari agregat alam yang penyerapan airnya berkisar 2-3\% (Kementerian PUPR, 2018).

Tabel 4. Berat jenis material

\begin{tabular}{lcccc}
\hline \multirow{2}{*}{ Material } & \multicolumn{3}{c}{ Berat Jenis } \\
\cline { 2 - 5 } & Bulk & SSD & Semu & Efektif \\
\hline Agregat Kasar : & & & & \\
Bongkaran Beton & 2,055 & 2,368 & 2,991 & 2,524 \\
Agregat Halus : & & & & \\
Bata Merah & 1,910 & 2,202 & 2,371 & 2,225 \\
Batako & 2,061 & 2,237 & 2,50 & 2,281 \\
Beton & 1,925 & 2,128 & 2,128 & 2,171 \\
Abu Sekam Padi & & & SG : 1,790 & \\
\hline
\end{tabular}


Tabel 5. Hasil Pemeriksaan Penyerapan Air Agregat

\begin{tabular}{|c|c|}
\hline \multirow{2}{*}{ Material } & \multirow{2}{*}{$\begin{array}{c}\text { Penyerapan Air } \\
(\%)\end{array}$} \\
\hline & \\
\hline Agregat Kasar & \\
\hline Bongkaran Beton & 15,22 \\
\hline Agregat Halus : & \\
\hline Bata Merah & 5,06 \\
\hline Batako & 8,53 \\
\hline Beton & 10,54 \\
\hline
\end{tabular}

Besarnya penyerapan pada agregat kasar atau agregat bekas bongkaran bangunan karena material agregat tersebut sebagian masih terlapisi dengan mortar pasir semen yang mempunyai daya serap air yang cukup tinggi.

\section{Keausan (Abrasi) Agregat Kasar}

Keausan agregat yang diuji dengan Mesin Los Angeles disajikan pada Tabel 2, dimana abrasinya sedikit lebih besar dari nilai maksimal 40\% (Kementerian PUPR, 2018)

.Tabel 6. Hasil pemeriksaan keausan (abrasi) agregat kasar

\begin{tabular}{cc}
\hline Material & Keausan (Abrasi) (\%) \\
\hline Agregat Kasar & 40,36 \\
\hline
\end{tabular}

Hasil pemeriksaan sifat lateks

Pemeriksaan berat jenis lateks dilakukan dengan metode pengujian menggunakan piknometer seperti yang dilakukan pada pemeriksaan berat jenis

Tabel 7. Hasil pemeriksaan lateks aspal. Pemeriksaan Kadar Karet Kering dilakukan untuk menentukan kadar karet kering. Hasil dari pemeriksaan ini adalah sebesar $67,2 \%$.

\begin{tabular}{clc}
\hline Material & \multicolumn{1}{c}{ Jenis Pengujian } & Hasil \\
\hline \multirow{2}{*}{ Lateks } & Berat Jenis & 1,113 \\
\cline { 2 - 3 } & Kadar Karet Kering & 67,2 \\
\hline
\end{tabular}

\section{Kadar lateks pada campuran}

Dari hasil trial direkomendasi memakai kadar lateks dalam campuran adalah kadar lateks minimum yg memberi sampel yang kompak dan stabil dengan

Hasil uji kuat tekan sampel yang di kondisikan dalam oven dengan suhu $40^{\circ} \mathrm{C}$ kuat tekan yang memenuhi syarat minimal $25 \mathrm{~kg} / \mathrm{cm}^{2}$, yaitu $5,65 \%$ terhadap berat total campuran dan divariasi sesuasi Tabel 3.

\section{Kuat tekan tanpa dan dengan rendaman} sampai berat konstan diperlihatkan pada Gambar 2 


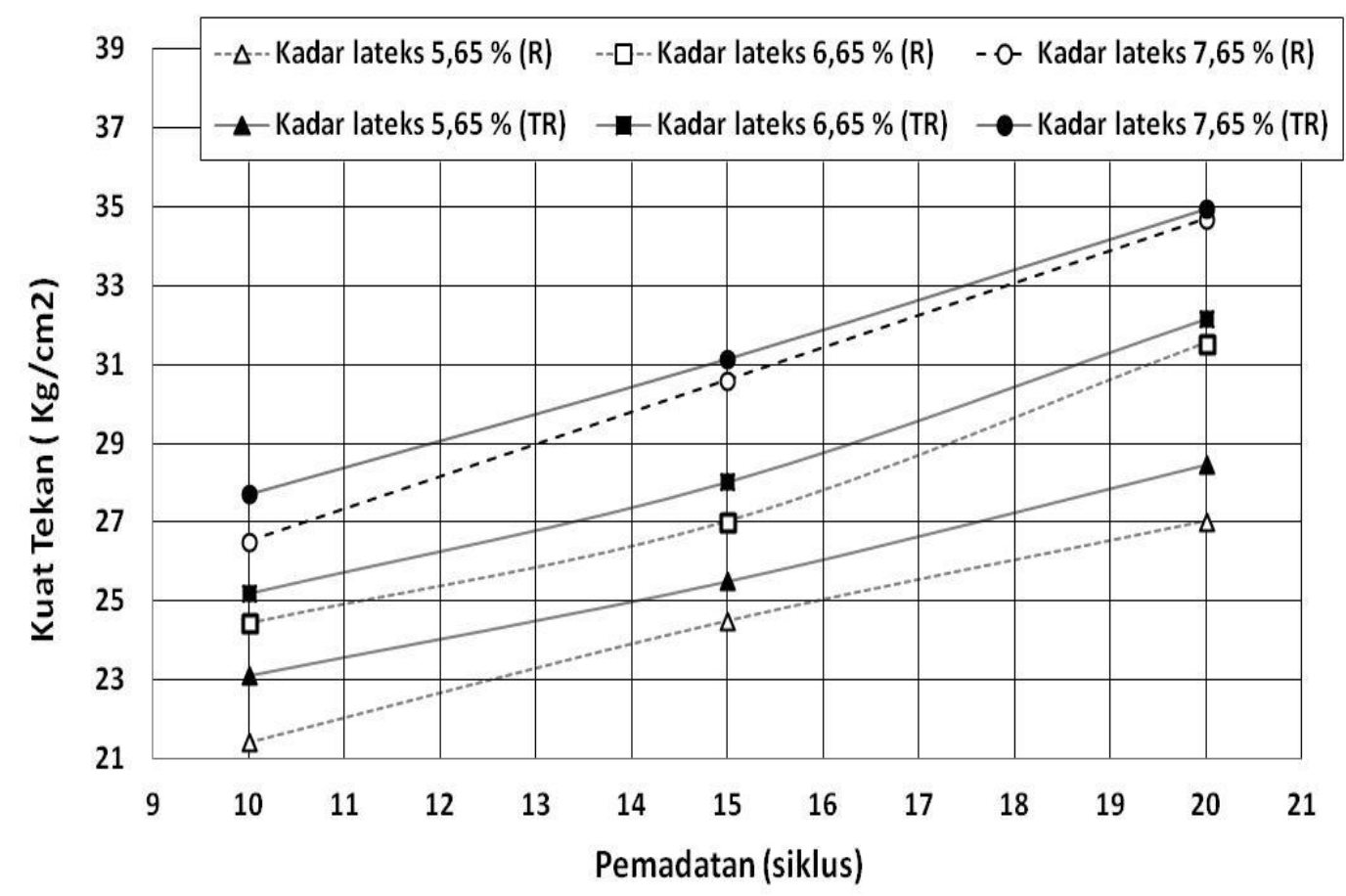

Gambar 2. Kuat tekan tanpa rendaman (TR) dan dengan rendaman (R)

Gambar 2 memperlihatkan bahwa sampel dengan rendaman 24 jam, memiliki kuat tekan lebih kecil dari yang tanpa rendaman pada kadar lateks yang sama. Untuk mencapai kekuatan minimal $25 \mathrm{~kg} / \mathrm{cm}^{2}$ pada sampel dengan rendaman (R) diperlukan kadar residu lateks yang paling tinggi yaitu $7,65 \%$ dengan tingkat pemadatan terendah (10 siklus pemadatan). Pada kadar lateks 6,65\%, diperlukan pemadatan minimal 15 siklus. Sedangkan sampel dengan kadar lateks $5,65 \%$ memerlukan lebih dari 15 siklus pemadatan.

Kuat tekan yang diperoleh lebih tinggi dari kuat tekan bahan dinding ringan. Bata ringan ada yang memiliki kuat tekan antara $5-10 \mathrm{~kg} / \mathrm{cm}^{2}$ (Taufik dkk., 2017). Bata beton ringan bias mencapai mendekati $10 \mathrm{~kg} / \mathrm{cm}^{2}$ (Eban et al., 2018). Sedangkan jenis bahan dinding bata dipasaran memiliki kuat tekan antara 25-40 kg/cm ${ }^{2}$ (PT. Tiga Mitra Surabaya, 2017).

Peneliti lain Arooz dan Halwature (2018), meneliti Mud-concrete block yang terdiri dari $30 \%$ agregat kasar, $60 \%$ pasir, $10 \%$ fines yang terdiri dari kombinasi lempung, lanau, dan pasir halus, dimana kadar semen antara 3-8\%. Campuran ini memiliki kuat tekan rendaman antara 10-30 $\mathrm{Kg} / \mathrm{cm}^{2}$. Selain itu (Holmes et al., 2016) meneliti blok bahan dinding (masonry block) yang terdiri dari agregat alam dan incinerator bottom ash (IBA) dari hasil pembakaran sistem pemanas batubara. Untuk campuran dengan penggantian agregat halus dengan $100 \%$ memakai IBA memiliki kuat tekan antara 3,5 sd 4,3 $\mathrm{MPa}$ $\left(35-43 \mathrm{~kg} / \mathrm{cm}^{2}\right)$.

Dari data tersebut blok bahan dinding yang diteliti disini memiliki kualitas yang sebanding dengan dengan yang diteliti peneliti lain dan yang ada dipasaran bahkan lebih baik dari bahan dinding ringan yang diteliti peneliti lain. Bila diberikan energi pemadatan yang lebih tinggi dari yang sudah diteliti akan meningkatkan kuat tekan.

\section{Initial rate of suction (IRS) dan penyerapan air}

Hasil uji IRS disajikan pada Gambar 3, sedangkan hasil uji penyerapan air diperlihatkan pada Gambar 4. Nilai IRS yang diperoleh tipikal dengan nilai IRS yang 
banyak terdapat di Inggris dengan nilai 0,25-2,0 kg/m ${ }^{2}$ menit (Vekey, 2001).

Nilai IRS yang lebih besar akan menyerap mortar perekat lebih banyak, sehingga blok bahan dinding perlu dibasahi sebelum dipakai. Penyerapan air yang diperoleh relatif kecil dibandingkan beton ringan dengan penyerapan antara 18,161 $\%-21,747 \%$ (Eban dkk., 2018).

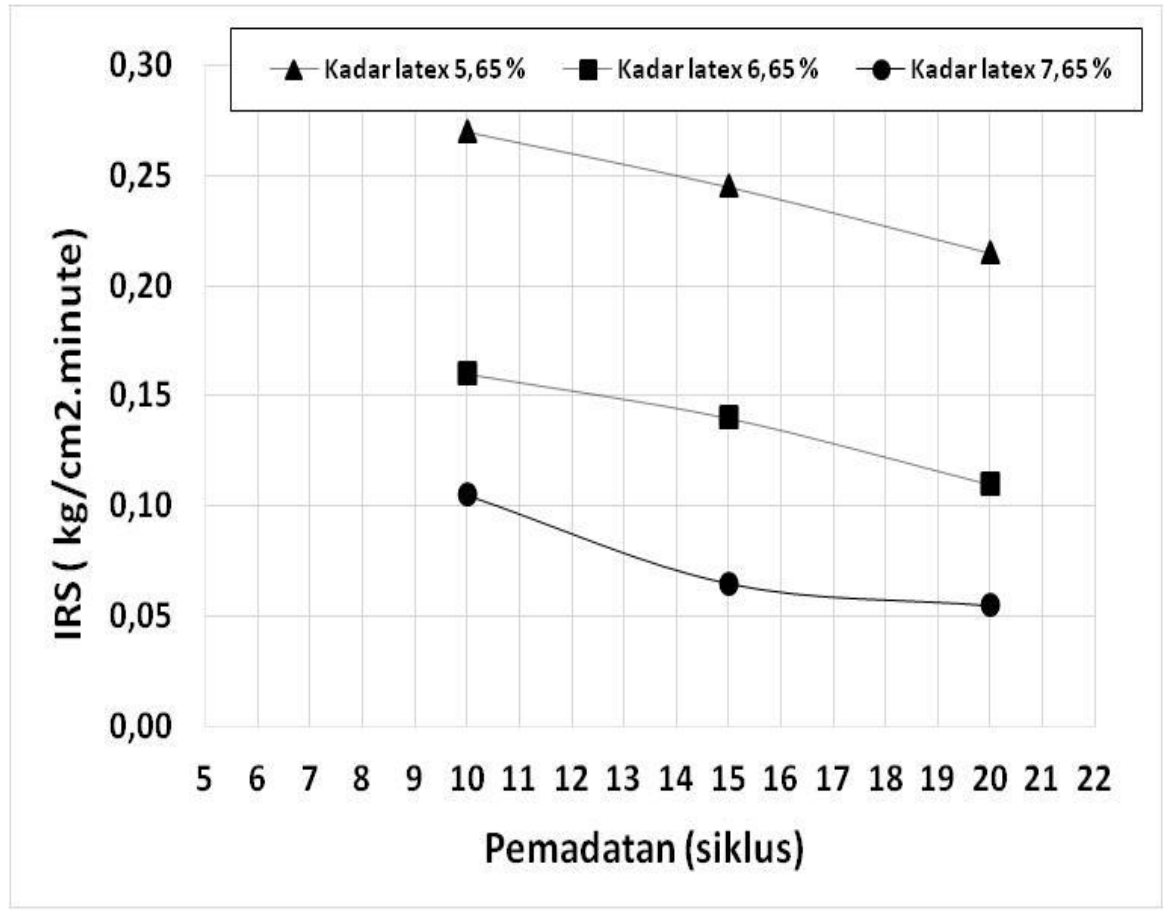

Gambar 3. Hasil Uji IRS

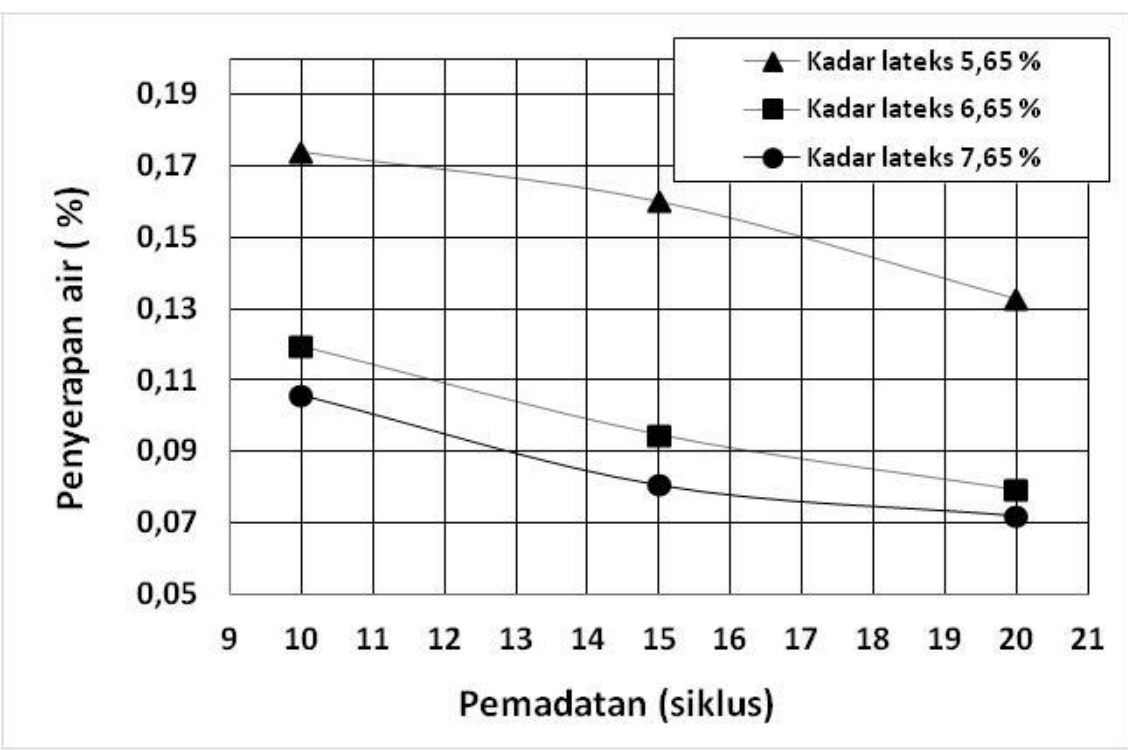

Gambar 4. Hasil uji penyerapan air 


\section{Porositas}

Hasil uji porositas diperlihatkan pada Gambar 5, dimana porositas diperoleh antara 0,50-3,0\% sesuai tingkat pemadatan yang dilakukan. Tidak ada spesifikasi perihal porositas. Nilai ini jauh lebih kecil dari porositas bata beton ringan dengan foam agent yg diteliti (Modestus et al.,
2017) yang memperoleh porositas bata beton ringan antara 27,54 - 30,33\% dan $21,73 \%$ untuk bata biasa. Selain itu (Rohman et al., 2018) yang juga meneliti beton ringan dari abu sekam dengan porositas $38,08 \%$.

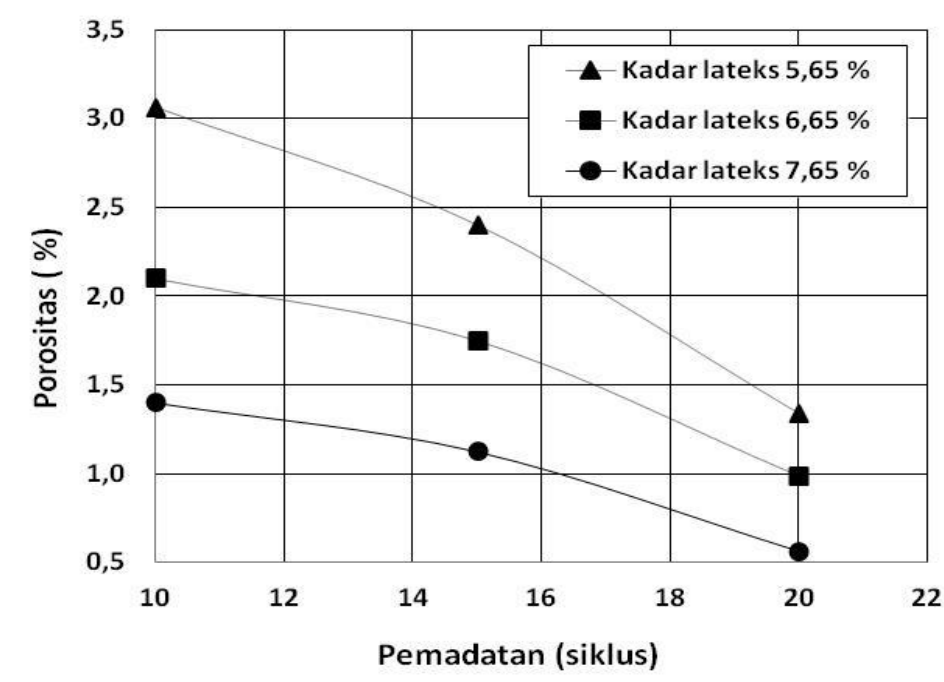

Gambar 5. Porositas sampel

\section{Peningkatan kuat tekan}

Peningkatan kuat tekan sampel dengan kadar lateks terendah 5,65\% dengan tumbukan 20 siklus dan dikondisikan pada suhu ruang di dalam lab (29-30 $\mathrm{C})$, diperlihatkan pada Gambar 6 . Sampel mencapai kuat tekan minimum $\geq 25$ $\mathrm{kg} / \mathrm{cm}^{2}$ setelah berumur 23 hari yaitu dengan kuat tekan $28,05 \mathrm{Kg} / \mathrm{cm}^{2}$. Sampel sudah cukup kuat atau stabil pada umur 3 hari dimana sampel tetap utuh pada saat diangkat dan peningkatan kekuatannya berlanjut setelah blok bahan ini dipasang.

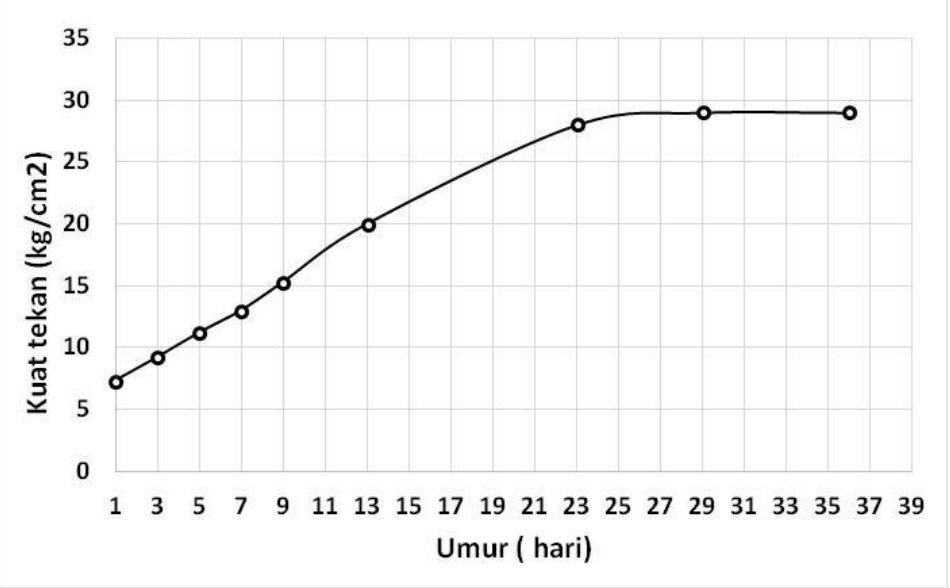

Gambar 6. Peningkatan kuat tekan 
Pengujian peningkatan kuat tekan dengan curing sampel pada suhu ruang ini memerlukan waktu lebih dari 3 minggu untuk mencapai kekuatan maksimal dibandingkan dengan cara curing dalam oven pada suhu $\pm 40^{\circ} \mathrm{C}$ yang memerlukan waktu 6 hari untuk mencapai kuat tekan maksimal.

\section{SIMPULAN}

Dapat disimpulkan karakteristik BBPD menggunakan agregat bekas dari bongkaran bahan bangunan dengan lateks sebagai bahan perekatnya, maka dapat ditarik kesimpulan sebagai berikut: Kualitas agregat bahan bekas bongkaran bangunan lebih kecil dari agregat yang biasa dipakai untuk beton atau bahan perkerasan jalan. Kadar lateks resedu minimum untuk BBPD adalah $5,65 \%$ dari berat total agregat. BBPD dapat mencapai kuat tekan sampai $34,95 \mathrm{~kg} / \mathrm{cm} 2$. BBPD mencapai kuat tekan minimum dicapai saat berumur 23 hari pada suhu ruang yaitu dengan kuat tekan 28,05 $\mathrm{Kg} / \mathrm{cm} 2$.

\section{DAFTAR PUSTAKA}

Alfa, A. A. dan Y. Syamsu. 2004. Sifat dan Kegunaan Karet Alam Siklik Dari Larutan Karet dan Dari Lateks. di dalam Prosiding Seminar Nasional VII Kimia Dalam Pembangunan, Hotel Santika Yogyakarta, 25-26 Mei 2004, pp. 540-547.

Arissa, K.W.T. 2016. Analisis Karakteristik Blok Bahan Pasangan Dinding Yang Memakai Bahan Bekas Garukan Aspal Beton Dengan Aspal Sisa Sebagai Perekat. Tugas Akhir, Jurusan Teknik Sipil Fakultas Teknik Universitas Udayana. (Tidak Dipublikasikan).

Arooz, F.R, Halwatura, R.U. 2018. Mudconcrete block (MCB): mix design \& durability characteristic. Case Studies in Construction Materials Journals, Science Direct, https://www.sciencedirect.com/scienc e/article/pii/S2214509517301250, https://www.sciencedirect.com/journal /case-studies-in-constructionmaterials/vol/8/suppl/C, diakses 22-62020.
Dewan Standardisasi Nasional (DSN). 1989. Mutu Dan Cara Uji Bata Beton Pejal.

Eban, K.K., Utomo, S., Simatupang, P.H. 2018. Perbandingan Kuat Tekan Bata Ringan CLC Menggunakan Pasir Gunung Boleng dan Pasir Takari. Jurnal Teknik Sipil, Vol. VII, No. 2, September 2018, Universitas Petra Surabaya.

Holmes, N., O'Malley, H., Cribbin, P., Mullen, H., Keane, G. 2016. Performance of masonry blocks containing different proportions of incinator bottom ash. Sustainable Materials and Technologies Journals, https://www.sciencedirect.co $\mathrm{m} / \mathrm{science} /$ article/pii/S2214993715300 117, diakses 22-6-2020

Industri Karet. 2008. Karet Alam. https://industrikaret.wordpress.com/20 08/05/12/karet-alam/, diakses 28-052020.

Kementerian Pekerjaan Umum Dan Perumahan Rakyat (PUPR). 2018. Spesifikasi Umum Untuk Pekerjaan Konstruksi Jalan Dan Jembatan.

Modestus, Sutandar, E., Samsurizal, E. 2017. Uji Individu Bata Ringan dengan Foam Agent Berdasarkan Variasi Ukuran Pasir. Jurnal Mahasiswa Teknik Sipil Universitas Tanjungpura.https://www.neliti.com/pu blications/190229/uji-individu-bataringan-dengan-foam-agentberdasarkan-variasi-ukuran-pasir, diakses 27-05-2020.

Nurhayati, C .2008. Penggunaan Lateks Karet (Hevea Brasiliensis) untuk Lem Kayu Lapis dengan Variasi Temperatur dan Waktu Depolimerisasi untuk Meningkatkan Mutu Lem. Jurnal Dinamika Penelitian Industri Vol. 29 No 2. Tahun 2018.https://media.neliti.com/media/p ublications/272513-none-

8cee926f.pdf, diakses 8-5-2020.

PT. Tiga Mitra Surabaya. 2017. Kuat Tekan Bata Ringan Dan Bata Merah. 
https://www.jualbataringan.com/2017/ 07/kuat-tekan-bata-ringan-dan-batamerah.html, diakses 15 Mei 2020.

Rambu, K. 2011. Analisis Karakteristik Blok Bahan Pasangan Dinding Menggunakan Variasi Komposisi Agregat Bekas Dari Bongkaran Bahan Bangunan Dengan Lemak Minyak Jelantah Sebagai Bahan Perekat, Tugas Akhir, Jurusan Teknik Sipil Fakultas Teknik Universitas Udayana. (Tidak Dipublikasikan)

Rohman, Nur, M. and WS. Brams, Dwandaru. W.S.B. 2018. Pengaruh Variasi Lama Pengeringan Dan Volume Larutan Graphene Oxide Berbahan Dasar Abu Sekam Padi Terhadap Kuat Tekan Dan Porositas Bata Ringan Jenis Cellular Lightweigt Concrete. Tugas Akhir, FMIPA Universitas Negeri Yogyakarta.https://eprints.uny.ac.id/5 6630/, diakses 27-05-2020.

Taufik, H., Kurniawandy, A., Arita, D. 2017. Tinjauan Kuat Tekan Bata Ringan Menggunakan Bahan Tambah Foaming Agent, Jurnal Saintis, Vol. 17 No. 1 (2017) , Universitas Islam Riau.

https://journal.uir.ac.id/index.php/saint is/article/view/1765, diakses 15 Mei 2020.

Thanaya, I N.A. 2010. Building Blocks Incorporating Waste Materials Bound
With Bitumen. Journal of Civil Engineering Science and Application: Civil Engineering Dimension. Volume 12, No.1, March 2010, Pp. 36-43, Petra Christian University, ISSN 14109530, Surabaya, Indonesia.

Vekey de, R.C. (2001). Construction Materials, Their Nature and Beahviour, Third Edition, Edited by J.M. Illston and P.L.J. Domone, Page 288, Spon Press, London and New York.

Wahyudi, F. 2008. Pengaruh Kombinasi Komposisi Bahan Olah Karet Terhadap Tingkat Konsistensi Plastisitas Retension Indeks (Pri) Karet Remah Sir 20 Di Pt. Bridgestone Sumatera Rubber Estate Dolok Merangir. Http://Repository.Usu.Ac.Id/Bitstream/ Handle/123456789/13962/09e00092. Pdf?Sequence $=1$ \&lsallowed $=Y$, diakses 20-05-2020.

Yudistira, I.D.G.R. 2017. Analisis Karakteristik Blok Bahan Pasangan Dinding (BBPD) Menggunakan Bahan Bekas Bongkaran Bangunan dengan Aspal Sisa sebagai Perekat. Tugas Akhir, Jurusan Teknik Sipil Fakultas Teknik Universitas Udayana. (Tidak Dipublikasikan). 